\title{
The Lunacy Commissioners and the East London Guardians, 1845-1867
}

\author{
ELAINE MURPHY*
}

\section{Introduction: \\ The Crystallization of Central Regulation}

The social history of insanity has proved a seductive paradigm for students of the management of the dependent poor in nineteenth-century England. Largely through Andrew Scull's work, the insane have been perceived as "casualties" of class and gender power relations during the transformation from paternalistic laissez-faire rural economy into an industrialized capitalist state. ${ }^{1}$ While the Elizabethan Poor Law was the administrative foundation on which the system of care was constructed, until recently two other themes dominated the historiography of mental disorder, first that of the rise of psychiatry and psychiatrists and second the expansion of the Victorian asylum as society's preferred response. ${ }^{2}$ The place of the insane in social welfare provision was located by Kathleen Jones and Scull in their early works within the reforming zeal of the county magistrates, the mid-Victorian Lunatics Acts and the central inspectorate responsible for policing the Acts, the Commissioners in Lunacy. ${ }^{3}$ The literature underplayed the legal and administrative context of the Poor Law within which lunacy was managed and paid only glancing attention to the influence of the changing role of the state and the growth of nineteenth-century government administration.

Over the past fifteen years, largely through the work of Peter Bartlett, David Wright, Leonard Smith, and Bill Forsythe and Joseph Melling, ${ }^{4}$ the asylum and "mad-doctors" have been repositioned on the periphery of a target that places the

* Professor Elaine Murphy, Honorary Senior Research Fellow at the Wellcome Trust Centre for the History of Medicine at University College London and Visiting Professor in Psychological Medicine at Queen Mary, University of London. Address for correspondence: North East London Health Authority, 81 Commercial Road, London E1 1RD.

\footnotetext{
'Andrew Scull, The most solitary of afflictions. madness and society in Britain, 1700-1900, New Haven and London, Yale University Press, 1993. See especially ch. 8, 'The legacy of reform', pp. 375-94.

$2 \mathrm{~J}$ Walton, 'Poverty and lunacy: some thoughts on directions for future research', Bull. Soc. soc. Hist. Med., 1984, 34: 64-7.

${ }^{3}$ Kathleen Jones, Lunacy, law and conscience, 1744-1845, London, Routledge \& Paul, 1955;
}

Andrew Scull, Museums of madness: the social organization of insanity in nineteenth-century England, London, Allen Lane, 1979.

${ }^{4} \mathrm{P}$ Bartlett, 'The asylum and the Poor Law: the productive alliance', in Joseph Melling and Bill Forsythe (eds), Insanity, institutions and society, 1800-1914, London, Routledge, 1999, pp. 48-67; David Wright, 'Getting out of the asylum: understanding the confinement of the insane in the nineteenth century', Soc. Hist. Med., 1997, 10: 137-55; L Smith, 'The county asylum in the mixed economy of care', in Melling and Forsythe (eds), ibid., pp. 33-47; Bill Forsythe, Joseph Melling, Richard Adair, 'The New Poor Law and the county pauper lunatic asylum: the Devon experience 1834-1884', Soc. Hist. Med., 1996, 9: 335-55. 
administration of the Poor Law at its centre. A reappraisal of the "revisionist" interpretation of events is now underway and a more complex picture is emerging. Mad paupers are no longer so readily annexed to political dogma.

The role of the Lunacy Commissioners and their relationship with central and local Poor Law administrators also requires revision. The two Lunatics Acts of 1845 engineered by Lord Ashley ${ }^{5}$ ushered in the machinery for the creation of comprehensive public provision of care for the insane. The Lunatics Asylums and Pauper Lunatics $\mathrm{Act}^{6}$ imposed on county and borough magistrates the obligation to establish lunatic asylums for pauper lunatics. The Lunatics Act ${ }^{7}$ established the Lunacy Commission, the national inspectorate with the responsibility to regulate and maintain standards.

The Lunacy Commissioners were charged with a wide-ranging set of tasks in relation to the confinement, care and discharge of detained lunatics of all classes in every type of public and private institution. They were also to oversee the implementation of the Asylums Act, a task for which they were equipped with few powers except that of persuasion. This new central inspectorate was established at a time of government enthusiasm for central regulatory bodies. Nicholas Hervey and David Mellett discuss the creation of the Commission within the context of changing conceptions of the role of government, the development of a central administrative bureaucracy and the rise of supervisory central agencies designed to oversee and "police" the implementation of central government policy through local government. ${ }^{8}$ The Lunacy Commission was established with unpredictably overlapping jurisdictions with the central Poor Law Commission (from 1848 the Poor Law Board) which posed serious problems for the exercise of their powers of persuasion with local guardians. The Lunacy Commission's main task in the early days was perceived by parliament to be the inspection and regulation of private licensed houses and county asylums. The Commission added parish and union workhouses to their workload, on the reasonable grounds that there were known to be huge numbers of lunatics in them, but received no regulatory powers over Poor Law establishments except visiting rights until $1862 .{ }^{9}$

The new Commission was small, six professional full-time inspectors-three lawyers and three doctors, supplemented by up to five honorary Commissioners supported by a full-time secretary and a trio of clerks. Squashed into inadequate offices in Spring Gardens, this small band had some difficulty coping with the rapidly growing volume of paperwork generated by the annual returns. Additional business was thrust on them as time went by. Ashley, the new Chairman, was keen for the Commission to remain small, essential, he declared, to maintaining a spirit of

\footnotetext{
${ }^{5}$ Ashley became the 7th Earl of Shaftesbury in 1851 .

${ }^{6}$ The Lunatics Asylums and Pauper Lunatics Act , $8 \& 9$ Vic. c. 126.

${ }^{7}$ The Lunatics Act, 8 \& 9 Vic. c. 100.

${ }^{8}$ Nicholas Bethell Hervey, 'The Lunacy

Commission 1845-63, with special reference to

the implementation of policy in Kent and Surrey',
}

PhD thesis, University of Bristol 1987, ch. 5, pp. 50-5; D J Mellett 'Bureaucracy and mental illness: the Commissioners in Lunacy 1845-90', Med. Hist., 1981, 25: 221-50.

${ }^{9}$ Peter Bartlett, The Poor Law of lunacy, London, Leicester University Press, 1999, . pp. 197-237. 
collaboration and harmony. ${ }^{10}$ Perhaps he also realized that he could better maintain control of Commission policy with a few close cronies. Attracting like-minded people and keeping them was essential to cultivating the Spring Gardens ethos. Between 1845 and 1900 only twenty-eight professional men occupied six positions, presided over by the permanent chairman, who died "in harness" in 1885 after fifty unbroken years of service, first with the Metropolitan and then with the national Commissioners in Lunacy.

When the Commissioners began work in 1845 , they gave priority to private licensed houses, lunatic hospitals and the fifteen county and borough asylums. But at the beginning of 1848 they decided to begin the enormous task of inspecting the lunatic wards of the several hundred workhouses and identifying and examining all pauper lunatics and idiots. They had heard repeated complaints from asylums and hospitals of the deplorable physical condition in which some paupers arrived at the asylum from workhouses and were well aware that guardians kept many pauper lunatics and idiots in workhouses by choice. The official annual returns of lunatics gave an indication of the number of more obvious cases kept in each house, but the Commissioners had no idea of the accuracy of these returns. Indeed, the Poor Law Commission was ignorant to a great degree about the numbers and conditions of lunatics in workhouses. If the Lunacy Commission was to be successful in pressing for the rapid creation of more county asylums and the closure of the private licensed houses, then it had to persuade the guardians of the unsuitability of their current provision.

This paper explores the influence of the Lunacy Commission on the boards of guardians' policies on services for insane people in east London. The struggle in metropolitan London between the Lunacy Commission, the guardians and the central Poor Law authorities for control over the lives of insane paupers, and reasons for the victory of central government are suggested. The dates 1845 to 1867 have been chosen to cover the period from the establishment of the Lunacy Commissioners until the passing of the Metropolitan Poor Act in 1867, which established imbecile asylums under the control of the central Poor Law authorities.

\section{The East London Unions}

The guardians of east London administered the new Poor Law in the most impoverished and heavily "pauperized" urban area in England and Wales. Extending east and north of the City of London, the Tower Division of the Ossulstone Hundred comprises the traditional "East End", that is the parishes and unions of Shoreditch, St George in the East, Whitechapel, Bethnal Green, Stepney, Poplar, plus Hackney and Stoke Newington. The main pressure on the workhouse masters was the inexorable growth in the numbers of paupers. Institutions that had housed 300 to 400 inmates in the mid-1830s held double or treble that number by 1845 . To contain

\footnotetext{
${ }^{10}$ Lord Shaftesbury, 'Evidence to the Select Committee on the Operation of Regulations for the Care and Treatments of Lunatics and their Property', Select Committee on Lunatics 1860,
}

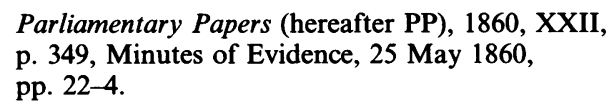
p. 349, Minutes of Evidence, 25 May 1860 , pp. $22-4$. 


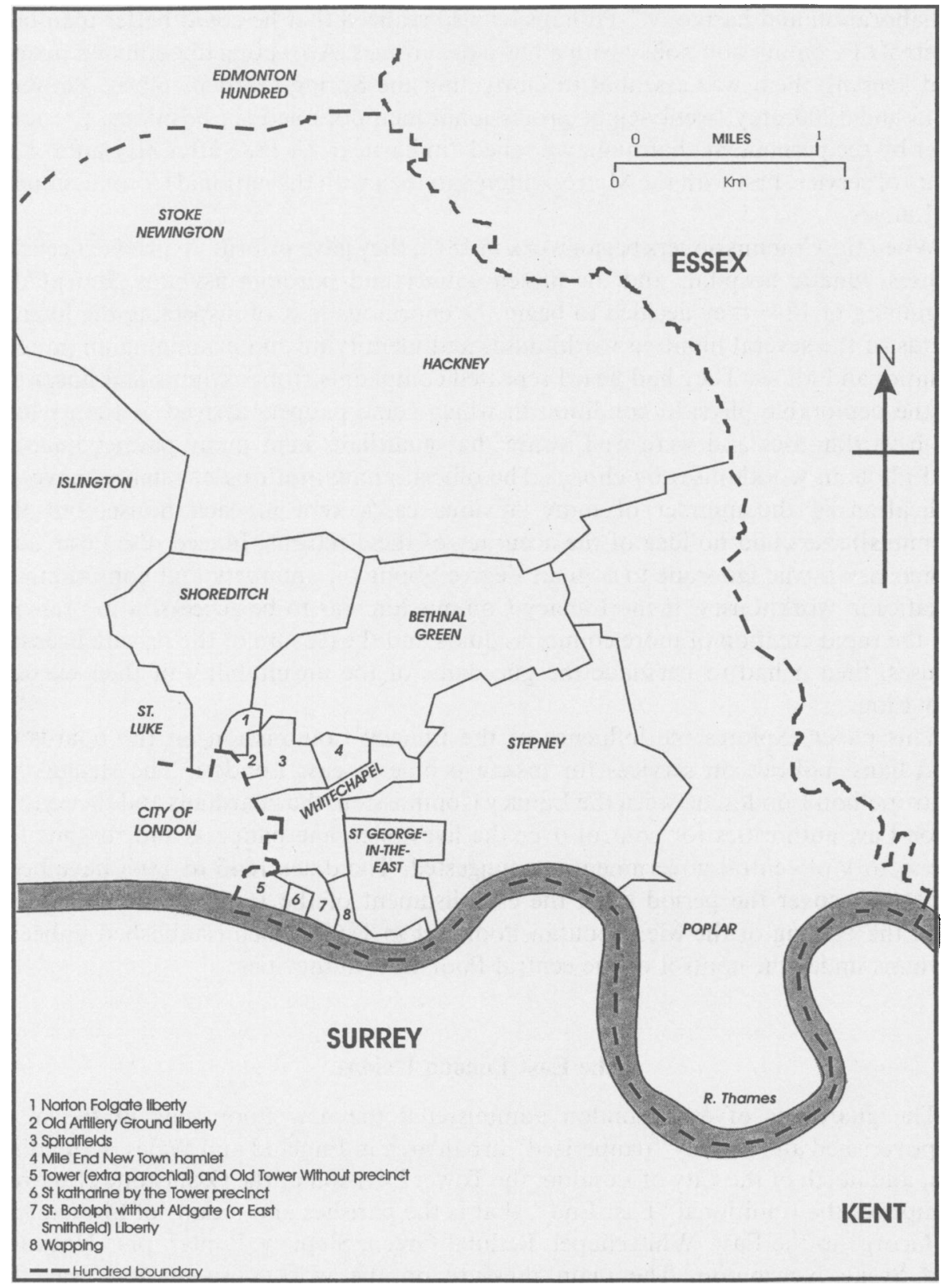

Figure 1: Middlesex: Ossulstone Hundred, Boards of Guardians in the Tower Division 1840 (reproduced from the Victoria County History, Middlesex, vol. X, p. 2, by permission of the General Editor). 
The Lunacy Commissioners and the East London Guardians, 1845-1867

the rising demand in the East End, most unions made alterations and expansions or built new larger workhouses but they never seemed to keep up with the inward flow. " By 1857 many eastern metropolis workhouses contained over 1000 paupers. Most east London unions had several expanding workhouses.

\section{The Lunacy Commissioners' First Visits to East London}

The Lunacy Commissioners were mindful that workhouses came under a separate government jurisdiction, that of the Poor Law Commission (from 1848 the Poor Law Board). Commissioners' reports to the county justices about conditions in public asylums were longer, more detailed and certainly more critical than their reports to the Poor Law Commission about workhouses. While the two central boards ostensibly had similar aims as far as lunatics were concerned and in public at least they made sure they appeared to be of one mind, politely backing each other's orders, relations between the two bodies were not quite so harmonious as the pleasantries suggest. The Poor Law Commission was there to concern itself above all else with the management of the able-bodied unemployed poor. The sick, infirm and medically incompetent were a complication to be dealt with but something of a side issue in the great national scheme to reduce pauperism. The Lunacy Commission on the other hand began their task steeped in Ashley's evangelical ethos of a public duty to provide care and cure. Lunatics were deserving of the best conditions that could be afforded, for humanity's sake.

From 1845-8, before the Poor Law Commission was disbanded and Chadwick was ousted from his job as Secretary to the Commission and effectively its day-today executive head, these two divergent philosophies could be accommodated in Somerset House and Spring Gardens. Chadwick personally saw no dissonance between his policy on the unemployed able poor and the need to provide for the dependent sick poor. Curiously, though Chadwick and Ashley had disparate ideologies and came from socially remote backgrounds, they shared a disposition to frantic overwork, a passionate zeal to get things done, a predisposition to meddle and a tendency to take offence. While frequently disagreeing over the detail, style and process of achieving change, they admired and respected each other. They remained lifelong friends after working together at the ill-fated Board of Health from $1848-54 .^{12}$

It was all very well for these two key people at the top of their respective administrations to believe there were no differences in objectives between Poor Law sick policies and the Lunacy Commission's aims, but, in practice, the Poor Law philosophy was impossible to deliver consistently. The harsh treatment imposed on the workless enveloped all paupers in those unions of a particularly unforgiving disposition. In the late 1840s numerous scandals were reported by a hostile press about the wretched inhumanity of workhouse conditions. The Andover workhouse

\footnotetext{
${ }^{11}$ David R Green, From artisans to paupers: economic change and poverty in London, 1790-1870, Aldershot, Scolar Press, 1995, pp. $210-47$.
}

${ }^{12}$ Georgina Battiscombe, Shaftesbury, London, Purnell, 1974, pp. 219-34; S E Finer, The life and times of Sir Edwin Chadwick, London, Methuen, 1952, p. 349. 
scandal, which disclosed that starving pauper inmates were reduced to gnawing the bones they were supposed to grind, broke in $1846 .{ }^{13}$

Responsible boards of guardians tried to steer a difficult course between the parallel tracks of Poor Law policy for the "deserving" and the "undeserving". ${ }^{4}$ Relieving officers and workhouse masters were reducing the comforts of paupers to comply with their interpretation of "less eligibility". At the same time they were expected to be generous "overseers" of the needy sick, ensure medical help was available to all, provide comfortable infirmary wards, and kindness to the sick and dying. The "able-bodied" workless and non-able-bodied paupers overlapped to such a degree that it was difficult in practice to draw a clear distinction between them. The Lunacy Commission had no such dilemma, being concerned only with the guardians' humanitarian responsibilities.

From 1845-8, Lunacy Commissioners took care not to tread on the sensibilities of their colleagues in the Poor Law Commission. If the Lunacy Commissioners were zealously critical of conditions in workhouses, there must be an implication that the Poor Law Commission had not been carrying out their own inspectorial function competently. In the early days this was easy because the Commissioners had little time to visit workhouses. The few they did visit attracted little comment. In the Lunacy Commissioners' first annual report, references to Poor Law institutions were remarkably bland, given the factual description of conditions the Commissioners found on their visits.

The paupers in workhouses who are labouring under insanity of an active form or of recent origin are comparatively very few; and in these cases the Guardians have in general been found well-disposed and ready of their own accord to take the necessary steps for their speedy transfer to a lunatic asylum. ${ }^{15}$

When the Commissioners encountered violent lunatics however, "we have never failed to interfere and insist upon immediate removal of the parties". The Lunacy Commission was hampered right from the start by section VIII of the 1845 Act which allowed guardians to extend existing lunatic wards and opened up the possibility of using the workhouse for chronic patients. Though the regulations necessary for this were not enacted until 1862, nevertheless, the seeds were sown for the later undermining of the asylums "ideal". Between June 1848 and June 1849, the year that the Poor Law Commission was disbanded and the new Poor Law Board established, the Lunacy Commission visited 248 workhouses. In the eastern metropolis they included the four Stepney Union houses and those in St George in the East and Poplar. ${ }^{16}$ The visit to Stepney in June 1849 was typical of many.

Every Thursday afternoon in the late 1840s, the four workhouse masters and Mrs Megson, the female "Master" of Wapping workhouse, attended the Stepney Board

\footnotetext{
${ }^{13}$ Report from the Select Committee into the administration of the Poor Law in Andover Union, 1846, Public Record Office (hereafter PRO), HC.633.

${ }^{14}$ Felix Driver, Power and pauperism: the workhouse system, 1834-1884, Cambridge University Press, 1993, pp. 66-71; Bryan Green,
}

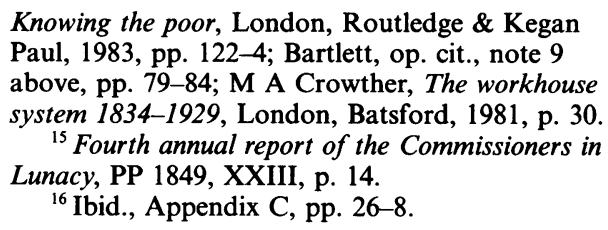


of Guardians' meeting at the union offices in Ratcliff workhouse to report on the week's unusual and untoward events. ${ }^{17}$ The inevitable scuffles and quarrels of institutional life were owned up to and any special cases reported. Lunatics who required certifying and removal to an asylum were mentioned because one of the Relieving Officers would have to request the attendance of a medical practitioner not employed directly by the parish to make the appropriate recommendation.

Life in the Stepney workhouses continued much as it had for the previous ten years since the Poor Law Amendment Act and the formation of the union board of guardians in 1836. The Poor Law Commission and its successor continued the deluge of central instructions, up to 2000 separate orders every year. Assistant Commissioner Richard Hall from Somerset House was just as demanding as his predecessors had been. Stepney's policy for insane paupers was to care for as many of them as possible in the two specially designated wards at Wapping workhouse, with a special nurse, Mrs Ransom, appointed for the task. ${ }^{18}$ The union retained nearly half (48 per cent) of their lunatics at Wapping. ${ }^{19}$ The guardians spent a middle-of-the-range amount on individual placements at Hanwell and private asylums, and were average spenders on lunatics compared with their neighbours in east London. ${ }^{20}$ The guardians inherited several usable, if not ideal, workhouses and from the outset they began the task of classification, shifting paupers around the district institutions until they had accumulated the "homogeneous" groups designated by the Poor Law Commission. ${ }^{21}$ The able-bodied men and older boys went to Limehouse workhouse, the lunatics shared Wapping with women and older girls, the children went to Mile End, and the aged and infirm to Ratcliff, but only if they were "reduced by misfortune, and had exemplary conduct". ${ }^{22}$

The guardians' visiting committee decided whether lunatics should be removed from the workhouse lunatic wards to a private asylum or to the Middlesex County Lunatic Asylum at Hanwell. ${ }^{23}$ For example, they found Margaret Waterers

... occasionally violent and her language indecent. Frequently in the habit of making great noise during the night which disturbs other lunatic patients. There is little possibility of recovery, [but] her removal to Bethnal Green would benefit other paupers. ${ }^{24}$

Their report implies that the expense of the private licensed house, Bethnal Green Asylum, normally had to be justified on the grounds of susceptibility to treatment,

\footnotetext{
${ }^{17}$ Minutes of the Board of Guardians of Stepney Union (hereafter Stepney Minutes), London Metropolitan Archive, St BG/L/16, 7 June 1849, pp. 46-51.

${ }^{18}$ Ibid., St BG/L/3, 7 Nov. 1839, p. 297.

${ }^{19}$ Annual returns of pauper lunatics, 1842 and 1843, University of London Library. Parliamentary Papers in Lunacy, vol. 3, pp. 371-415. Middlesex Returns 405. Charles Dickens visited Mrs Megson's workhouse at Wapping twice, once in early May 1850 and a decade later in early 1860 . Charles Dickens, 'A walk in the workhouse', Household Words, 25 May 1840, pp. 204-7; idem, 'The uncommercial
}

traveller', All the Year Round, 18 Feb. 1860; Elaine Murphy, 'The administration of insanity in East London 1800-1870', PhD thesis, University of London, 2000, pp. 131-45.

${ }^{20}$ Elaine Murphy, 'The New Poor Law Guardians and the administration of insanity', Bull. Hist. Med., forthcoming.

${ }^{21}$ Driver, op. cit., note 14 above, pp. 95-111.

${ }^{22}$ Stepney Minutes, St BG/L/1, 21 Dec. 1836.

${ }^{23}$ Thirty-third report of the Visiting

Committee of Stepney Union, Stepney Minutes, St BG/L/3, 18 Nov. 1839.

${ }^{24}$ Stepney Minutes, St BG/L/3, 19 Dec. 1839. 


\section{Elaine Murphy}

but on this exceptional occasion they were willing to dispatch her on the grounds of ungovernability. From 1844, if Hanwell County Asylum was full, the board delegated the choice of private asylum to the parish doctor. The union clerk arranged for several cases to be considered as a single agenda item every few weeks and the vast majority of the doctors' recommendations were accepted.

At the guardians' meeting on 7 June 1849, the masters reported that the new Commissioners in Lunacy had visited for the first time. Mr Gaskell and Mr Mylne had visited three of the four workhouses that week. ${ }^{25}$ The two gentlemen had inspected all the rooms, "examined the idiots, lunatics and insane persons" and made a report on all three houses in the visitors' book at Ratcliff workhouse. Mrs Megson seized the opportunity to point out to the board that the Commissioners had declared "the Building known as the foul ward is not a proper place for lunatics". Mrs Megson was a remarkably kind and considerate, but firm, manager of her charges, persistently battling with other local Stepney workhouse masters and the guardians for her fair share of the resources for improving the comforts, the diet and opportunities for recreation and occupation of her charges. Charles Dickens was struck by her good sense and kindly disposition when he visited in 1850 and later in $1860 .^{26}$ Ably supported by the clerk, William Baker, whenever he felt able, she was successful in campaigning for new equipment, an improved diet and better linen but was less successful in persuading the guardians to invest in capital expense for improving the fabric of the buildings. The subject of her many complaints and suggestions in the past, the foul ward housed sick and destitute old women, wornout syphilitic prostitutes and scabby infected derelicts, all squashed into the same old wards as the female lunatics at Wapping workhouse. Suitable neither as an infirmary nor as dormitories for the fit, Dickens thought it "a kind of purgatory". ${ }^{27}$ The Chairman, Thomas Fry, asked for the Commissioners' full report to be read out.

(Visit to Ratcliff on 4 June '49). These paupers were, at the time seen, with a few exceptions tranquil and comfortable and were generally speaking tractable and harmless. In the house at Wapping however the Commissioners found one of the females named Frances Middlemore who was in a great state of maniacal excitement and was in a strait waistcoat and Eliza Wells and Frances Brown, both of whom were in a state of melancholia and under delusions who might in their judgement to be removed without delay to a lunatic asylum and if Martha Thompson were to bear removal which however may be doubted, as she is apparently in a very feeble state and is paralysed a similar step would be advisable in her case.

A large portion of the Idiotic in that workhouse are placed among the invalids in the outbuilding or as it is termed the foul ward, a building which in point of construction and arrangement is wretchedly ill adapted for the reception and accommodation either for the sick or the imbecile and idiotic, many of whom are subject to epilepsy.

The accommodation provided for the idiotic and imbecile at Mile End Workhouse is somewhat better although it is still extremely defective. Of the paupers whom the

\footnotetext{
${ }^{25}$ Stepney Minutes, St BG/L/16, 7 June 1849, pp. 46-51.

${ }^{26}$ Dickens, 'A walk in the workhouse', p. 207; idem, 'The uncommercial traveller', see note 19 above for both.
} 


\section{The Lunacy Commissioners and the East London Guardians, 1845-1867}

Commissioners examined at the latter house, L.J. Tilson might be removed to a lunatic asylum and the same course ought probably be taken with Henry Harrison and also with Daniel Connor and William Hunt should they be found not to improve in their present situation.

The board directed the relieving officers to look into the cases mentioned and make transfer arrangements if necessary. The new Commissioners were going to cost them money. The same week the Poor Law Board had sent an inspection team round all the Stepney houses to check on the ventilation systems, which the guardians knew were defective; that was going to cost them money too. They had no money for upgrading the foul wards and Mrs Megson was still battling to get some improvements when Charles Dickens visited a decade later.

Workhouse visits were conducted in the usual Commission manner by two Commissioners, one medical (in Stepney's case, Sam Gaskell) and one legal (in Stepney, James Mylne) ${ }^{28}$ It was a mammoth task. The Poor Law Commission had issued an order in 1845 banning Bethnal Green guardians from squeezing more than 1016 people into their already overcrowded house. All the Stepney houses except Ratcliff, the small well-built infirmary house, had 600 to 700 inmates. Visits were of necessity relatively short. A cursory look around the wards and a brief conversation with the patients identified by the master or matron as appropriate for their attention, was all that could be managed in the half a day allocated for each visit. Not all the Commissioners were as thorough as Gaskell and Mylne. ${ }^{29}$ When Thomas Turner and William Campbell visited Hackney Workhouse in 1850 they merely left a note in the visitors' book saying "They were all in a tranquil state and no one was under mechanical restraint. The house was clean and in good order." 30 This may have been accurate but the report was surprisingly short.

The Commission took a pragmatic line on special lunatic wards in workhouses, such as the one Stepney had set up in the late 1830s at Wapping. This had become a general infirmary "foul ward" by 1849 , whereas in many districts such wards had become more specialized. "There are now a considerable number of workhouses in which separate apartments or buildings, termed Idiot or Lunatic Wards, have been fitted up expressly for paupers of that class." 31 They employed special attendants, the inmates were allowed a more liberal diet, and "in some respects they are similar to ordinary lunatic asylums". The Commission was doubtful whether these places were "legal" but thought it right to visit them more frequently than ordinary workhouse wards. ${ }^{32}$

\footnotetext{
${ }^{28}$ Nicholas Hervey, 'A slavish bowing down: The Lunacy Commission and the psychiatric profession 1845-60', in W Bynum, R Porter and M Shepherd (eds), The anatomy of madness, London, Tavistock, 1985, vol. 2, pp. 98-131; Hervey, op. cit., note 8 above, ch. 5 .

${ }^{29}$ Andrew Scull, Charlotte Mackenzie, Nicholas Hervey, Masters of Bedlam: the transformation of the mad-doctoring trade, Princeton University Press, 1994, pp. 161-86.
}

\footnotetext{
${ }^{30}$ Minutes of the Hackney and Stoke Newington Board of Guardians, London Metropolitan Archive, Ha BG/10, 28 Oct. 1850, p. 174.

${ }^{31}$ Third annual report of the Commissioners in Lunacy, PP 1848, XXII, Supplementary report on workhouses, Appendix A, 1847-8, section xxxii, p. 371.

${ }^{32}$ Ibid., pp. $370-3$.
} 


\section{Elaine Murphy}

Workhouse patients designated as lunatics have often been characterized as harmless imbeciles, chronically but quietly mad or decrepit old dements. Scull describes the characters that populate the borderlands of the state of lunacy:

Chronic alcoholics afflicted with delirium tremens or, with permanently pickled brains, reduced to a state of dementia; epileptics; tertiary syphilitics; consumptives in the throes of terminal delirium; cases of organic brain damage ... the malnourished, the simple-minded. ${ }^{33}$

Certainly those that remained in the workhouse in the longer term seem to have fitted this description in the early years after the Lunatics Act of $1845 .{ }^{34}$ Bartlett points out, however, that by 1861 the Lunacy Commissioners recognized that in many workhouses with designated lunatic wards, "The class of patients found in these wards differs little, if at all, from those met in County Asylums". ${ }^{35}$ The workhouse infirmary had a key role as a diagnostic "station stop" for a diverse assortment of cases brought in by the relieving officers and parish doctors for assessment and classification. About 15 per cent of infirmary admissions in east London were suffering primarily from mental disorder, a hefty chunk of the doctor's workload. ${ }^{36}$

The Metropolitan Commissioners' 1844 survey had identified several parishes and unions that sub-contracted part of their workhouse or a separate building as a private licensed house solely for the benefit of their own paupers. ${ }^{37}$ Bethnal Green guardians gave serious consideration to setting up their own lunatic asylum wards in a separate building in 1846, because the private Bethnal Green Asylum thought that the erection of county lunatic asylums would rapidly ruin their business and intended to raise their prices in anticipation of future losses. ${ }^{38}$ Since Hanwell had been open for thirteen years with little permanent effect on trade, this may have been just this year's excuse to increase the price. ${ }^{39}$ One of the guardians, Charles Jennery, estimated that if part of the house were refurbished for lunatics, for a capital outlay of say $£ 1000$, the annual revenue savings would be between $£ 400$ and £500. The board decided to seek the views of the Poor Law Commission and the Lunacy Commission. ${ }^{40}$ Chairman William Howard dampened Jennery's enthusiasm by pointing out that both Commissions were bound to want a well fitted up new, separate building at a cost of at least $£ 2000$. The new regulations would require the lunatic wards to have a resident medical officer and special attendants; savings would be small. The guardians reluctantly abandoned the idea. ${ }^{41}$

\footnotetext{
${ }^{33}$ Scull, op. cit., note 1 above, pp. $344-52$.

${ }^{34}$ Third annual report of the Commissioners in Lunacy, PP 1848, XXII, Supplementary report on workhouses, Appendix A, 1847-8, section xxxii, p. 371 .

${ }^{35}$ Peter Bartlett, 'The asylum, the workhouse and the voice of the insane poor', Int. J. Law Psychiatry, 1998, 21: 421-32; Fifteenth annual report of the Commissioners in Lunacy, PP 1861, XXVII, section xxvii, pp. 1, 47.

${ }^{36}$ Figure from Shoreditch Workhouse admission books, vol. 5, 1862-70, London Metropolitan Archive, film X20/170.
} 


\section{The Lunacy Commission and the Poor Law Board}

Relations between the Lunacy Commission and the new Poor Law Board established in 1848 began amicably enough. ${ }^{42}$ The Commissioners found people they thought sufficiently violent to warrant removal concentrated in thirty-two workhouses, including Mile End and Wapping. "The Poor Law Board have always zealously co-operated with us to ensure this object has been effected". ${ }^{43}$ A lack of suitable asylum places available for the transfer of lunatics out of workhouse wards imposed a degree of caution on the Commissioners in recommending too many transfers. They complained repeatedly about the lack of recent cases being sent to the new public asylums and their filling up with incurables. It was hardly consistent then to insist on the transfer of long-standing cases unless there were statutory reasons for doing so.

The two inspectorates maintained a united public front but became increasingly frustrated with the other's attitude. As the Poor Law Board assumed more direct responsibility and executive powers over the boards of guardians, they became more sympathetic to the guardians' desire to run the pauper management machine as cheaply as the local ratepayers wanted. Specialist lunatic placements were expensive. Even though the ratepayers paid for them, the guardians had little influence over county asylum costs. There were, moreover, thousands of harmless lunatics and imbeciles in workhouses cared for alongside other paupers and the Lunacy Commissioners had rarely complained to unions about their care when they visited - surely conditions could not be all that bad? Bartlett and Hervey point out that, wherever possible, the Lunacy Commissioners adopted a conciliatory, incrementalist style with local officials; their reports were rarely very critical. ${ }^{44}$

The Poor Law Board's views were not put into plain words until the Select Committee on Lunatics hearings of 1859 and 1860 , but there is enough in the correspondence to suggest that there was simmering resentment in the Poor Law authority of the moral superiority assumed by the Lunacy Commissioners for several years before that. ${ }^{45}$ The Board's lack of sympathy for special treatment of lunatics came over powerfully in the Select Committee hearings on Lunatics in 1859.

Although the main reason for establishing the Select Committee was public concern about illegal or unwarranted confinement in private asylums, it followed the stinging

\footnotetext{
${ }^{42}$ Minutes of meetings of the Commissioners in Lunacy, 1845-March 1851, PRO, series MH50/ $1-4$, indexed MH50/40,41; Correspondence between the Poor Law Board and the Lunacy Commissioners, PRO, series MH19/168, 169, 170; Legal opinions relating to workhouses requested by Lunacy Commissioners, PRO, series MH51/ 749, 760; Miscellaneous Home Office papers referring to lunatics and the Poor Law Board, PRO series HO45, see particularly 6686,7269 , 7102, 7512, 7520, 7751, 7592.
}

\footnotetext{
${ }^{43}$ Fourth annual report of the Commissioners in Lunacy, PP 1849, XXIII, pp. 13-14.

${ }^{44}$ Bartlett, op. cit., note 9 above, pp. 209-13; Hervey, op. cit., note 8 above, pp. 94ff, and chs 5 and 6.

${ }^{45}$ Correspondence between the Poor Law Board and the Lunacy Commissioners, PRO, series MH19/168, 169, 170; Correspondence, Secretary to the Lunacy Commission to Assistant Secretary Poor Law Board, PRO, 1854, MH19/ 168.
} 


\section{Elaine Murphy}

report on workhouses that the Lunacy Commissioners added as a supplement to their 1858 annual report, perhaps a rather surprisingly critical overview given the bland local reports that preceded it. ${ }^{46}$ Bartlett suggests that the Lunacy Commission felt threatened by the investigation into their role in licensed houses and saw proposals that Poor Law medical officers should regulate committals to asylums as a threat to the Commission's power and authority. The Commission was fighting for survival during the Select Committee hearings. ${ }^{47}$

Andrew Doyle, the Poor Law Inspector for the northwest, challenged directly Shaftesbury's highly critical evidence to the Committee about workhouse care. Doyle expressed the opinion that it should be possible to detain lunatics formally in workhouses and, further, that the Poor Law inspectors were quite as capable as Lunacy Commissioners of supervising their care. ${ }^{48}$ Shaftesbury may have regretted the "softly, softly" approach which his Commissioners had taken in their early reports about workhouses. It certainly made it difficult for him to back up his opinion that there was much cruelty and thoughtless treatment of chronic lunatics and idiots in workhouses, and that their treatment was detrimental to their health and wellbeing. Even at the Select Committee hearings, Commission witnesses said they had received support from the Poor Law Board in pressing for improvements, although this may have been simply a display of reluctance to pick a quarrel in public at that point in the Inquiry.

Doyle's raw attack on the Lunacy Commission policy of pressing for the removal of lunatics from workhouses to asylums stung Shaftesbury into a more frank criticism of the quality of Poor Law Board supervision of their institutions. The final report from the Select Committee of 1860 leaned to Shaftesbury's view. That did nothing to foster harmony between the two inspectorates. ${ }^{49}$ Bartlett concludes that the friction between the two central bureaucracies was in part just "sibling rivalry" between agencies with overlapping jurisdictions. ${ }^{50}$ Territorial demarcation lines and the lines of accountability of the guardians and their officers required the Lunacy Commissioners to rely quite heavily on the Poor Law Board to create the pressure to implement changes.

From 1860 on, the Poor Law Board began their campaign to by-pass the Lunacy Commissioners by promoting the idea that all new provision for lunatics, including asylums for the class of chronically insane patients that posed such a heavy nursing burden on workhouses, should come under Poor Law control. From 1860 the Lunacy Commission rarely commented on institutions under Poor Law jurisdiction in their

\footnotetext{
${ }^{46}$ Twelfth report of the Commissioners in Lunacy, PP 1858, XXIII, p. 25, and Supplementary report on workhouses in England; Thirteenth report of the Commissioners in Lunacy, PP 1859, XIV, p. 73.

${ }^{47}$ Bartlett, op. cit., note 9 above, pp. 218-24.
}

\footnotetext{
${ }^{48}$ Andrew Doyle, Evidence to the Select Committee on Lunatics, PP 1859, Session 2, VII, pp. 501, 156.

${ }^{49}$ Report of the Select Committee on Lunatics, PP 1860, XXII, p. 394.

${ }^{50}$ Bartlett, op. cit., note 9 above, pp. 213-18.
} 
The Lunacy Commissioners and the East London Guardians, 1845-1867

annual reports although they continued to send weekly reports of their visits to the Poor Law office. ${ }^{51}$

\section{The Rising Numbers of Insane in Workhouses}

While the numbers of insane paupers sent to private licensed houses and asylums dropped markedly after the opening of Colney Hatch in 1851, the numbers of insane retained in workhouses continued to rise over the next decade. The Lunacy Commissioners observed that nationwide, an increasing number of unions seemed to be opening specialist insane wards. This puzzling phenomenon warranted enumeration. In 1862 the Commission issued a Special Return requesting the number of' such wards in each workhouse and the numbers of insane paupers admitted to the workhouse in the year $1861 .^{52}$

Stepney, the first East End union to establish lunatic wards, was also the first to abandon them, using asylums for preference from 1849. The union was, however, still using workhouses to receive emergency cases while admission to an asylum was being arranged, although this is not obvious from the returns. The union thought that workhouses should provide for the day-to-day admission of the despairing and transiently distressed. Bethnal Green, after rejecting the idea of separate provision for lunatics in 1846, mixed the insane with other inmates. Hackney also officially had no insane ward. All other east London unions had identified special wards. There were approximately 200 official "insane beds" in east London workhouses.

The Commissioners kept up their visits to workhouses and asylums at a punishing pace from 1845 to 1855 . The guardians took these annual visits more seriously as the Commissioners became more adept at recruiting the support of colleagues on the Poor Law Board to press a particular case or desirable change. In the early years, the Commissioners had made a note in the workhouse visitors' book and assumed that their comments would be brought to the attention of the board. In efficient Stepney they were. In St George in the East and Bethnal Green, it seems they were not. The masters did not always notify the guardians of the Commissioners' remarks, or if they did, not in such a way that demanded any action. Later the Commissioners adopted the practice of sending a written report directly to the Poor Law Board as well as leaving a note in the visitors' book. The central Board then took up specific points directly with the guardians. In these routine cases at least the two central agencies collaborated amicably enough.

The Commissioners returned to Bethnal Green, visited Hackney Workhouse and both Whitechapel houses, in Charles Street and in Mile End Road, in 1851. Nationally, "the numbers of insane poor detained in workhouses is diminishing in a very marked degree" but this was not the case in the metropolis. ${ }^{53}$

${ }^{51}$ Letters from Commissioners in Lunacy to Poor Law Board, 1860-80, PRO, MH19/168-180.

52 "Return of Unions in which Sane are intermixed with the Insane and where Lunatic Wards have been Established, Numbers of Lunatics in Each Separate Ward together with
Number of Lunatics Received into Workhouses from January 1861 to January 1862", quoted in Sixteenth annual report of the Commissioners in Lunacy, PP 1862, XXIII, Appendix G, p. 217.

${ }^{53}$ Ibid., pp. 20-1. 


\section{Elaine Murphy}

Joseph Nash is Medical Officer and visits several times daily. Mr Nicholas Murrell is Master. There are separate wards for lunatics, the bedding and clothing is sufficient but not very clean or orderly. The female lunatic ward is still as reported in the last visit of the Commissionersvery dark and cheerless and the airing court extremely confined. One small room serves as a day room and dormitory for nearly 20 patients. There are few seats, no easy chairs and by no means sufficient table accommodation.

The patients are tranquil and said not to require mechanical restraint. Those patients that are mixed with the other inmates are better accommodated. John Marr is under a certificate and will be removed as soon as a vacancy can be found in an asylum. The patients are not allowed a superior diet unless they are on the sick list. ${ }^{54}$

This report was included with Assistant Commissioner Hall's report of his visit to the disorderly receiving ward in May 1851 when he had found mothers and infants sharing an insufficient number of beds and that all too common economy measure, two men in each male bed. The Whitechapel Guardians were concerned enough about this letter to send the visiting committee to have a look. They recommended "ventilating glass in the hall windows, the lunatic wards to be limewhited and if practicable a new window to be put in to the wall". A long list of furniture was needed for wards 18, 20,25, 24 and 49. This gives some idea of the vast size of the Mile End workhouse, each ward having twenty or so inmates. Finally, they suggested "that Nathan Levy, Lunatic[,] be immediately removed to an asylum at any cost, he disturbing the whole house night and day".55

The Commissioners' report had sat unnoticed in the visitors' book for three months before the Poor Law Board sent their reminder. The guardians' visiting committee had made no comment on these conditions earlier. It is not clear whether its members were complacent, slackly attentive to detail or concentrating their visits elsewhere. The guardians took action after this visit-they ordered new furniture, set alterations in train, made enquiry about where to send Nathan Levy. He was consigned to Kent County Lunatic Asylum soon after. ${ }^{56}$

Kent Asylum was willing to accept paupers from other counties to fill their beds. Middlesex had always adhered to the rule that Hanwell was for Middlesex paupers only, except for those without a settlement who were paid for by the Common Fund. After the first year Hanwell did not have the vacancies, even if they had been willing to accept out-of-county cases. In the run-up to the opening of Colney Hatch in August 1851 there was not a single vacancy in any licensed house or asylum in east London. By the end of 1850 , Stepney was spending $£ 730$ per quarter on lunatics and idiot placements in addition to maintaining the wards at Wapping and Mile End. ${ }^{57}$ The quarterly accounts record costs as follows:

\footnotetext{
${ }^{54}$ Whitechapel Board of Guardians' Minutes (hereafter Whitechapel Minutes), London Metropolitan Archive, St BG/Wh/13, visit 28 Feb. reported 14 May 1851, p. 16.

${ }^{55}$ Ibid., pp. 16-17.
}

\footnotetext{
${ }^{56}$ Ibid., pp. $370,480$.

${ }^{57}$ Mile End was part in Stepney, part in Whitechapel. There were Mile End workhouses in both unions.
} 
The Lunacy Commissioners and the East London Guardians, 1845-1867

$\begin{array}{lr}\text { Hanwell } & £ 215 \text { 16s } 0 \mathrm{~d} \\ \text { Warburton's } & £ 71 \text { 10s } 0 \mathrm{~d} \\ \text { Bryan's } & £ 28 \text { 12s } 0 \mathrm{~d} \\ \text { Aubin's } & £ 227 \quad 4 \mathrm{~s} \quad 8 \mathrm{~d} \\ \text { Byas' } & £ 159 \quad 6 \mathrm{~s} 11 \mathrm{~d} \\ \text { Kent County Asylum } & £ 28 \text { 16s } 4 \mathrm{~d}\end{array}$

Sorely pressed for accommodation for lunatics, east London unions were tempted to avail themselves of the offer which arrived in early 1851 from their former Assistant Commissioner, Mr Mott, to take their insane paupers into his own asylum, Haydock Lodge in Lancashire. ${ }^{58}$ Having calculated the expense of such distant placements however, "neither the distance nor price appeared to enlist the Guardians" feelings and they declined the proposal". They hung on using ad hoc placements at Kent County Asylum until Colney Hatch opened. Kent was then the nearest available county asylum to east London.

\section{The Poor Law Board in the Ascendancy}

By the late 1850s, the Commissioners had more than enough to do overseeing the mushrooming asylums and reduced their workhouse visits. The number of asylums and the number of detained patients to be visited were multiplying. The asylums that they had done so much to nurture were turning into vast institutions. Some years the Commissioners did not visit workhouses at all, or if they did, did not feel it was worth commenting on the conditions they found in their annual reports. "The great bulk of persons [in workhouses] are feeble or defective ... being in most cases of a congenital or organic and therefore of a permanent nature ... not likely to benefit from treatment" ${ }^{59}$ Instead of an asylum, the Commissioners prescribed work, which they felt would raise the self-esteem and improve the mental condition of these unfortunates. The main benefit an asylum could offer, the Commissioners felt, was treatment. If a patient was beyond treatment the only point in transferring him or her to an asylum was to control violent and difficult behaviour.

In 1867, as part of their campaign to promote the Metropolitan Asylums Bill, the Poor Law Board published an entire decade of reports by the Commissioners in Lunacy to the Poor Law Board from 1856 to 1866, and the correspondence between them on the subject of the metropolitan workhouses. ${ }^{60}$ The overall impression is of gravely inadequate care in defective institutions, although none of the individual reports is especially shocking or noteworthy. Care in workhouses was not uniformly bad. Frances Power Cobbe, in her critique of the New Poor Law, commented:

\footnotetext{
${ }^{58}$ Whitechapel Minutes, St BG/Wh/13, letters in Feb. 1851.

${ }^{59}$ Sixth annual report of the Commissioners in Lunacy, PP 1851, XXIII, Appendix D, Visits to workhouses, p. 20.
}

\footnotetext{
60 'Reports of Commissioners in Lunacy to the Poor Law Board on the state of imbecile wards in the metropolitan workhouses and of the correspondence between', Accounts and papers No. 23, PP 1867, LXI, pp. $194-444$ (hereafter 'Imbecile wards in the metropolitan workhouses')
} 


\section{Elaine Murphy}

Workhouses are lunatic asylums for all except violent cases. Many of them contain scores of insane patients. Here a total different order of things comes in view. The Commissioners mercifully intervene in favour of these poor souls, and compel the Guardians to treat them in a manner superior to other inmates in many respects. The appearance of their wards, decently furnished and often adorned with prints and supplied with objects for their amusement, is at first a surprise to the workhouse visitor.

Cobbe objected to the lack of specific medical treatment for mental disease in workhouses and wanted more insane moved to asylums for that reason alone, not because the general care was poor. ${ }^{61}$ The City of London Guardians argued that their policy of placing patients according to individual needs was better able to respond to variations between patients than a plan to build a remote asylum that would offer only one solution. ${ }^{62}$ The City aldermen remained unconvinced of the Lunacy Commission's arguments in favour of public over private asylums and could see no sense in building an institution of their own when there were ample satisfactory places locally. They had a point-Bethnal Green Asylum was getting better annual reports from the Commissioners in the 1840s and early 1850 s than many public asylums. Indeed it was an exemplary asylum and was the subject of a special report by the Commissioners in $1847 .^{63}$

Lunacy Commissioners' reports tended to be similar to the one before in content, differing only in style between visiting Commissioners. Sam Gaskell, W G Campbell and Robert Nairne were careful but genially encouraging and understanding. John Forster and Bryan Procter were less sympathetic; their detailed accounts left no stone unturned. Officious Lutwidge was downright bad tempered. ${ }^{64}$ These reports chronicle the swings in efficiency of union administration, guardians' responsiveness to criticism and their changing attitudes to caring for idiots and long-term mentally dependent patients. Over a five-year period an effective administration could sink into deplorably poor habits; a good workhouse might become filthy and dilapidated within a few months of losing a competent master. Conversely a determined board could transform the accommodation, care and therefore the lives of the lunatic inmates. The one union that received enthusiastic praise for its splendid workhouse was the City of London Union's "Grand Hotel", the Bow Institution, 65 "a house of

\footnotetext{
${ }^{61}$ Frances Power Cobbe, 'The philosophy of the Poor Law and the report of the Committee on Poor Relief', Fraser's Magazine, 1864, p. 70, reprinted in A W Coates (ed.), Poverty in the Victorian age: debates on the issue from 19th century critical journals. Vol II. English Poor Laws 1834-1870, 4 vols, Farnborough, Clegg, 1973, pp. 373-94.

${ }^{62}$ Letters between Shaftesbury, the Secretary of State and City of London Guardians, Sixth annual report of the Commissioners in Lunacy, PP 1851, XXIII, pp. 9-10; Seventh annual report of the Commissioners in Lunacy, PP 1852, XLIV, p. 10; Eighth annual report of the Commissioners in Lunacy, PP 1854, XXIX, p. 27.
}

\footnotetext{
${ }^{63}$ Further report of the Commissioners in Lunacy to the Lord Chancellor, PP 1847, XXXII, Appendix G, pp. 337-43.

${ }^{64}$ John Forster, historian, friend and biographer of Dickens. R W S Lutwidge became a full Commissioner after retiring as first Secretary of the Commission. He was attacked by a patient on a visit to Fisherton House Wiltshire in 1873 and died as a result. R Hunter and I Macalpine, Psychiatry for the poor: 1851 Colney Hatch Asylum-Friern Hospital 1973, a medical and social history, London, Dawsons, 1974, p. 107.

${ }^{65}$ City of London Corporation Workhouse is now St Clement's Hospital, Bow, a psychiatric hospital.
} 


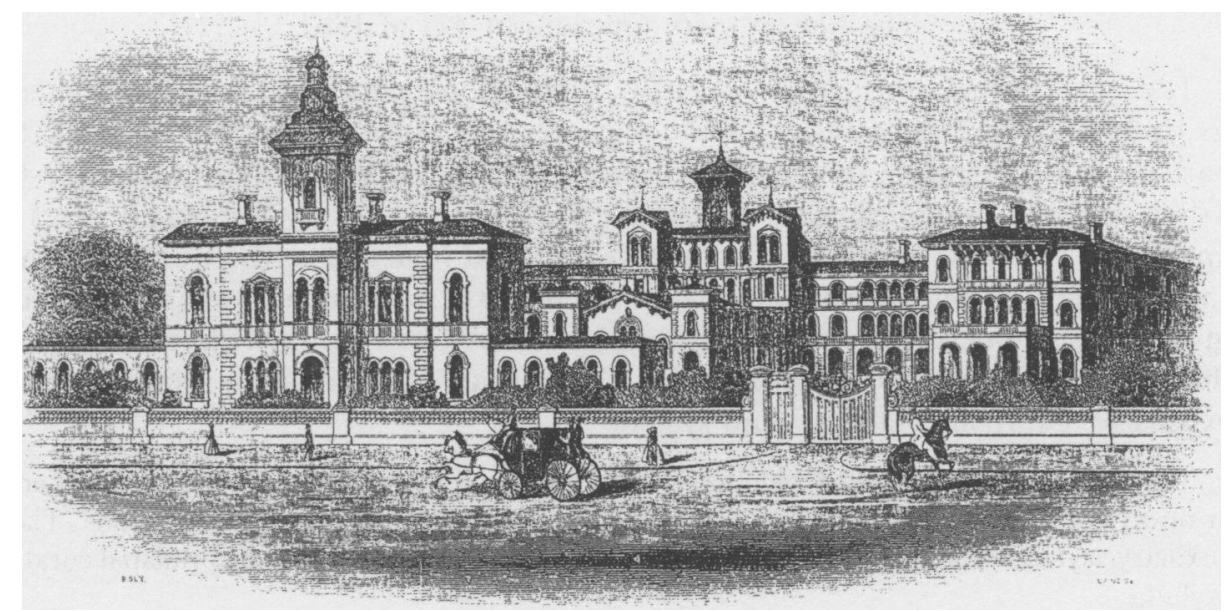

Figure 2: City of London Union Workhouse, designed by Mr R Tress. (Source: Builder, 1848, vol. 7, p. 323.)

architectural pretensions". ${ }^{66}$ The Lunacy Commission suggested other unions visit Bow to see how their lunatic and imbecile wards were managed. St Leonard's, Shoreditch, modelled their new wards on the Bow example in $1863 .{ }^{67}$

The rented workhouse of the St Luke's Old Street Union in the City Road was typical of many Gaskell, James Wilkes, Procter and Forster criticized between 1857 and $1861 .{ }^{68}$ There were so many mentally disordered people in the huge institution that "the workhouse is substantially a lunatic asylum and ought to have the ordinary comforts and conveniences of one", remarked Forster in 1858. The wards were crowded, the yards too small, there were insufficient staff, the diet was inferior, 72 patients were in crowded lunatic wards who "want of such treatment as only an asylum can afford". The guardians were unresponsive. The medical officer, $\mathrm{Mr}$ Harris, denied there were any lunatics in the workhouse requiring an asylum: they were all tranquil and manageable. As to the suggestion that there should be more attendants, the Chairman, George Whittle, wrote that "The present attendants ... suffer from want of scope for energetic exertion", there was insufficient work for them to do; it would be pointless appointing more. The Commissioners complained repeatedly to the Poor Law Board about the lack of action in "this discreditable workhouse". Henry Farnell, the local Poor Law Inspector, carried out a detailed inquiry in October 1861. Conditions remained essentially unchanged until 1867. Conditions at St Luke's represented a conspicuous failure for both central inspectorates.

${ }^{66}$ 'Imbecile wards in the metropolitan workhouses', op. cit., note 60 above, p. 194. 'Lancet Sanitary Commission for investigating the state of infirmaries in workhouses. No. I. Metropolitan infirmaries', Lancet, 1865, ii: 14-22.

\footnotetext{
${ }^{67}$ 'Imbecile wards in metropolitan workhouses', op. cit., note 60 above, pp. 401-3.

${ }^{68}$ Ibid., pp. $224-51$.
} 


\section{The Lunacy Acts Amendment Act of 1862}

The legal context in which the Lunacy Commissioners operated shifted marginally to their advantage as a result of the Lunacy Acts Amendment Act of 1862, the parliamentary response to the Select Committee on Lunacy Inquiries of 1859-60. While originally established to investigate a number of highly publicized cases of apparently sane people being unjustifiably confined in asylums, the Committee was soon persuaded that the really pressing issue in the care of lunatics was the difficulty in meeting the demand for asylum places. ${ }^{69}$ In their Report to the Select Committee, the Commissioners had recommended that as an alternative to expanding the expensive, curative county asylum system,

... the erection of inexpensive buildings adapted for the idiotic, chronic and harmless patients, in direct connexion with, or at a convenient distance from, the existing institutions. These auxiliary asylums would be intermediate between union workhouses and the principal curative asylums. $^{70}$

Shaftesbury had in mind that these new asylums would fall under the control of the justices and the provisions of the Lunacy Acts. The 1862 Act disappointed the Commission by sanctioning the transfer of the harmless chronically insane and imbecile from Lunatic Asylums to workhouses subject to approval by the Secretary of State. ${ }^{71}$ In practice the Lunacy Commissioners made the recommendation for the licence to be granted. As a consolation prize the Commission was given powers to remove lunatics from workhouses to asylums when they considered it necessary, a power they would need to use sparingly. The object was to speed up the flow of patients between different parts of the system. A year later, the Amending Act of 1863 awarded the Commissioners a veto over the transfer of lunatics to workhouses in the event of the workhouse having unsatisfactory facilities. ${ }^{72}$ The Committee of Asylum Visitors had to make the formal application rather than the guardians, a safeguard against the wholesale removal of patients from asylums as a cost-reducing exercise.

The 1862 Act was the first breach of the Lunacy Commission's treasured principle that all insane patients should be removed from the control of the Poor Law Authorities to the protection of the justices and the Lunacy Act. Until then the Commission had assumed it was merely a matter of time and sufficient expenditure by the Justices before all mentally dependent people were transferred out of the control of the guardians. The guardians were not pleased with the 1862 Act either, because it appeared to encourage workhouses to turn into small lunatic asylums. A quarter or so of the pauper lunatics declared on the annual returns were maintained

\footnotetext{
${ }^{69}$ Daniel Hack Tuke, Chapters in the history of the insane in the British Isles, London, Kegan Paul, Trench, 1882, pp. 147-203, 192; Report from the Select Committee on Lunatics, PP 1859 , VII, Session 2, First report, pp. 48-52; Report from the Select Committee on Lunatics, PP 1860, XXII, p. 394.

70 'Supplementary report' to the Twelfth annual report of the Commissioners in Lunacy, PP 1859,
}

'Evidence to the Select Committee on Lunatics', Session 1, IX, p. 1.

${ }^{71}$ Lunacy Acts Amendment Act, 1862, 25 \& 26 Vic. c. 111, Section 8.

${ }^{72}$ Ruth G Hodgkinson, 'Provision for pauper lunatics 1834-1871', Med. Hist. 1966, 10: 138-54. 
in local workhouses and it seemed likely that an even higher proportion would be left there in the future. The Poor Law Board tried to reassure the guardians that this was not intended. ${ }^{73}$

Mile End fitted up lunatic wards on the ground floor of the infirmary block at the new Bancroft Road workhouse. ${ }^{74}$ There were no paid attendants for these wards and only one nurse employed for the whole infirmary, although she had been recruited from Colney Hatch Asylum so as to provide some expertise in the lunatic wards. The accommodation was clean and pleasant enough and the visiting Commissioners broadly satisfied with the care. ${ }^{75}$ Lutwidge quibbled about some minor details, but Mile End received statutory approval for its special lunatic wards in 1863, and took twenty patients back from Colney Hatch. By 1864 they had seventy-five lunatics and imbeciles in special wards and the regime was considered good. There were outings organized to Victoria Park and Epping Forest, various amusements and a good diet. Chronic patients inevitably accumulated: Mile End guardians wanted to add a third storey to the lunatic wards in 1863. Lutwidge's swift, irrascible response to the expansion plan was "the proposal ... should be at once negatived". The Commissioners did not like ward blocks over two stories. So what should the Guardians do about the overcrowding, they asked? Buy more land was the inevitable answer.

The majority of east London unions used their workhouses as the first point of admission for acute cases of insanity. The relieving officer would bring in the patient, the workhouse medical officer would decide whether removal to an asylum was required, then the committal would be completed by the agreement of a local clergyman. (A clergyman could substitute for a magistrate in committal proceedings until 1889). Patients would remain in the workhouse for several weeks while a decision was made about their future unless their behaviour was so unmanageable that an early transfer to an asylum was warranted. Many unions preferred to delay admission to see if the patient would settle sufficiently to go home, which many did within a few days. ${ }^{76}$ Lunacy Commissioner Wilkes drew attention to the difficulties this posed for untrained workhouse staff. Caroline Robinson, for example,

[was] sent to the workhouse in an insane state having attempted to cut her own throat and threatened her husband's life. After being in the House a fortnight she seized a table knife for the purpose of again cutting her throat (which she did to a slight extent) but in getting the knife from her she received a very severe wound on the hand. I strongly recommend that whenever practicable the relieving officers should be instructed to send insane persons direct to the asylum without passing through the workhouse. ${ }^{77}$

Few unions took notice of the Commissioners' exhortations not to use the workhouse as an assessment/receiving place for the insane. It was geographically convenient,

\footnotetext{
${ }^{73}$ Gwendoline M Ayers, England's first state hospitals and the Metropolitan Asylums Board 1867, London, Wellcome Institute of the History of Medicine, 1971, p. 41.

${ }^{74}$ Mile End Workhouse survives as Mile End Hospital. A new psychiatric unit is currently being planned.
} 
required no formal certification procedure and many patients recovered and went home very quickly. With luck, the expense of an asylum stay could be avoided. The admission procedure established in the mid-nineteenth century, to a local institution followed by discharge home or placement in an asylum, established a pattern of clinical assessment that remained broadly the same in London until the closure of the large asylums in the late twentieth century.

Whitechapel Union had two large workhouses, in Charles Street and Whitechapel Road. A responsible and responsive union by the late $1850 \mathrm{~s}$, Whitechapel retained only twenty-two chronic insane patients in the House in 1857. Commissioners Nairne, Campbell and Lutwidge gave good reports overall of the standards of care in 1857, 1860 and $1863 .{ }^{78} \mathrm{~A}$ new workhouse and infirmary was built in $1860-61$ but it quickly proved too small and unsuitable for the growing number of imbeciles. In 1865, Farnell, the Poor Law Inspector, suggested that they could construct a new building for imbeciles on land the union owned at Forest Gate next to the union schools, but the guardians were not receptive to that idea. Alterations and extensions to the new workhouse provided new imbecile wards in $1866 .{ }^{79}$

The parish of St Leonard's, Shoreditch, struggled to provide a decent environment in an ancient workhouse built in 1777. The building was huge, overflowing with unclassified patients. One medical officer "devotes much attention to the patients" Gaskell thought, and the Board was ever willing to accept suggestions for improving the wards but somehow never got round to doing anything about it during the late $1850 \mathrm{~s}^{80}$ Instead they began planning an ambitious new workhouse and infirmary that would be the envy of other unions. It was a long time coming; it took until 1865 to finish the new building and in the years between 1859 and 1865 conditions at St Leonard's deteriorated to the point of being scandalous. The wards became infested with bed bugs, the sanitary facilities were gravely inadequate, there were no WCs with trap pans, only open earth closets and smelly old latrines. "The Insane Wards are of a prison-like character", "the yards are surrounded by high walls and comfortless airing courts", which several attempts at planting had done little to soften. $^{81}$

\section{The Lunacy Commission upstaged by the Lancet Commission}

The Lunacy Commissioners were good at spotting problems on their intermittent visits to workhouses but not sufficiently influential or powerful to disturb the guardians' habitual institutional inertia. They could not make the guardians spend money and they could not insist on staffing levels being increased. They worked on the "drip, drip" principle of continually criticizing the same things, hoping to wear down the guardians into accepting their suggestions, but the guardians were masters

\footnotetext{
${ }^{78}$ Ibid., pp. $434-9$.

${ }^{79}$ Ibid., p. 443.

${ }^{80} \mathrm{D}$ A Brassett, St Leonard's Hospital, 1863-1963, London, 1964. Hackney Archive Department, Y 1137/362, St Leonard Shoreditch,
}

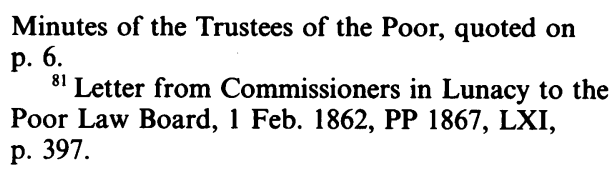


of procrastination and not very susceptible to exhortation. If they felt inclined to accept the suggestions and criticisms, things got done; if not, nothing changed.

The Commission did not seek to influence public opinion through the trade and general press. They worked through the conventional methods of publishing adverse material in their annual report, occasionally through judicious use of prosecutions of frank ill treatment, and regularly tried to enlist the support of Poor Law Board colleagues, but they never felt able to use the shock tactics that enlisted public support. It was not in Shaftesbury's nature to take that approach. In contrast, the Lancet published a series of dramatic reports during 1865 and 1866 by three doctors, Carr, Anstie and Hart, who visited workhouse infirmaries on the journal's behalf to report on conditions. Grandly called the "Lancet Sanitary Commission for Investigating the State of the Infirmaries in Workhouses", every fortnight for a year one or more of the metropolitan workhouses was described in horrifying detail. ${ }^{82}$ It was marvellous sensationalist reporting.

The Lancet report on St Leonard's, Shoreditch, was typical. ${ }^{83}$ The workhouse "combines the principal merits and defects of the system". The history of its management was "paved with good intentions" and there was "much goodwill and openness. The Master [Mr Painter] is an able, business-like and judicious official. The Medical Officer [James Clark] is a man of considerable vigour, long experience and kindly nature" but:

If we have to show that the infirmary is a terrible failure, and the whole state of things in it disgraceful to the parish and to the country, we must ask that a great allowance be made for the superhuman difficulties of the task which would be involved in a fitting administration by this one gentleman of the duties which are properly incidental to the management of so large a hospital as this.

They commented on the extreme cheerlessness and the desolation of the imbeciles:

Moping about in herds, without any occupation whatever; ... congregated in a miserable day-room, where they sit and stare at each other or at the bare walls ... treated ... as we would kennel dogs in decent kennels ... We denounce the cruelty of keeping these imbeciles in a cheerless town workhouse.

There was just one medical officer for the 700 inmates, and one paid nurse. The male pauper nurses "struck us as a peculiarly rough, ignorant and uncouth set". There were no night nurses. The imbeciles were better off than the sick, whose sores were covered in rags for want of bandages, the wards "frequently filthy with crusted blood and discharges". A man with gangrene lay unattended on a hard straw mattress, medicines were dished out in a haphazard fashion from huge pots with little regard to prescription. The Lancet's visitors pondered how good men with fine aspirations could ignore the frightful conditions. They concluded that the guardians, the medical officer and the master were "deadened by long routine".

\footnotetext{
${ }^{82}$ Lancet Sanitary Commission, op. cit., note 66 above.

83 'Lancet Sanitary Commission visit to St Leonard's, Shoreditch. No. III, Metropolitan
}

infirmaries', Lancet, 1865, ii: 131-3, quotes on p. 132. 


\section{Elaine Murphy}

The Morning Advertiser and The Times immediately picked up this dynamite prose ${ }^{84}$ The Shoreditch guardians were forced to respond publicly and made much of the progress of the new building, defending the care of imbeciles who they said were "often taken out in vans into the Forest" for their amusement. ${ }^{85}$ They could point to the elegant brand new "offices of the poor" as evidence of their commitment. They defended themselves as well as they could, but this stinging, very public humiliation did the Shoreditch guardians a power of good. They made major investments; smartened up their public image, and commissioned a suitably impressive façade and fashionable mansard "French château" style roof for their new workhouse infirmary building. The Lancet had suceeded with one article where the Lunacy Commissioners and Poor Law Board had failed in a decade of reports.

The three Lancet doctors were merciless about Bethnal Green's relatively new workhouse, constructed in 1840. The prison-like three-storey building was so overcrowded it was necessary to crawl "crab-fashion" between the beds in the 27 sick wards painted in stark, chilling white. Imbeciles were mixed in unclassified wards, unless so uncontrollable they were sent to the asylum. "The male insane ward is a disgrace to the institution". Small, dark, ill-ventilated and with no outlook because the windows were 6 feet off the floor, the rooms were "utterly unfit for the purpose". ${ }^{86}$

\section{The "Irresponsible Guardians"}

The Lancet men concluded: "the conditions of imbeciles in London workhouses is a deeply painful subject". They singled out the "oasis" at St Marylebone, with a garden, bird-cages, rabbit hutches and pictures, but that was exceptional. The Lancet had no faith in the ability of the London guardians or workhouse staff to run hospitals, regarding them as responsible for the "monstrous deficiencies" ${ }^{87}$ Both the Lunacy Commissioners and the self-appointed Lancet Commissioners demonized the guardians, perhaps unfairly, given the cash constraints of the rating system and their impoverished populations. In their 1867 report, the Commissioners deplored the "disposition to withdraw them [lunatics] from the protection of the lunacy laws and place them under the irresponsible care of the Guardians", language that fifteen years earlier would have been unthinkable. The unions were working with a percapita budget less than half that available to the magistrates, and modest compared to the budget creamed off later from the Metropolitan Common Poor Fund by the Metropolitan Asylums Board.

There was no drive to remove chronic harmless cases to asylums by 1865 . The report of the first meeting of the newly named Medico-Psychological Association (the old Association of Medical Officers of Asylums and Hospitals for the Insane) that year makes it very clear that insane persons came in desirable and undesirable forms.

\footnotetext{
${ }^{84}$ The Morning Advertiser, 5 Aug. 1865, and The Times, 12 Aug. 1865.

85 'Report on complaints in The Times by the Clerk to Shoreditch Guardians', Lancet, 1865, i: 187-9, on p. 187.
} 


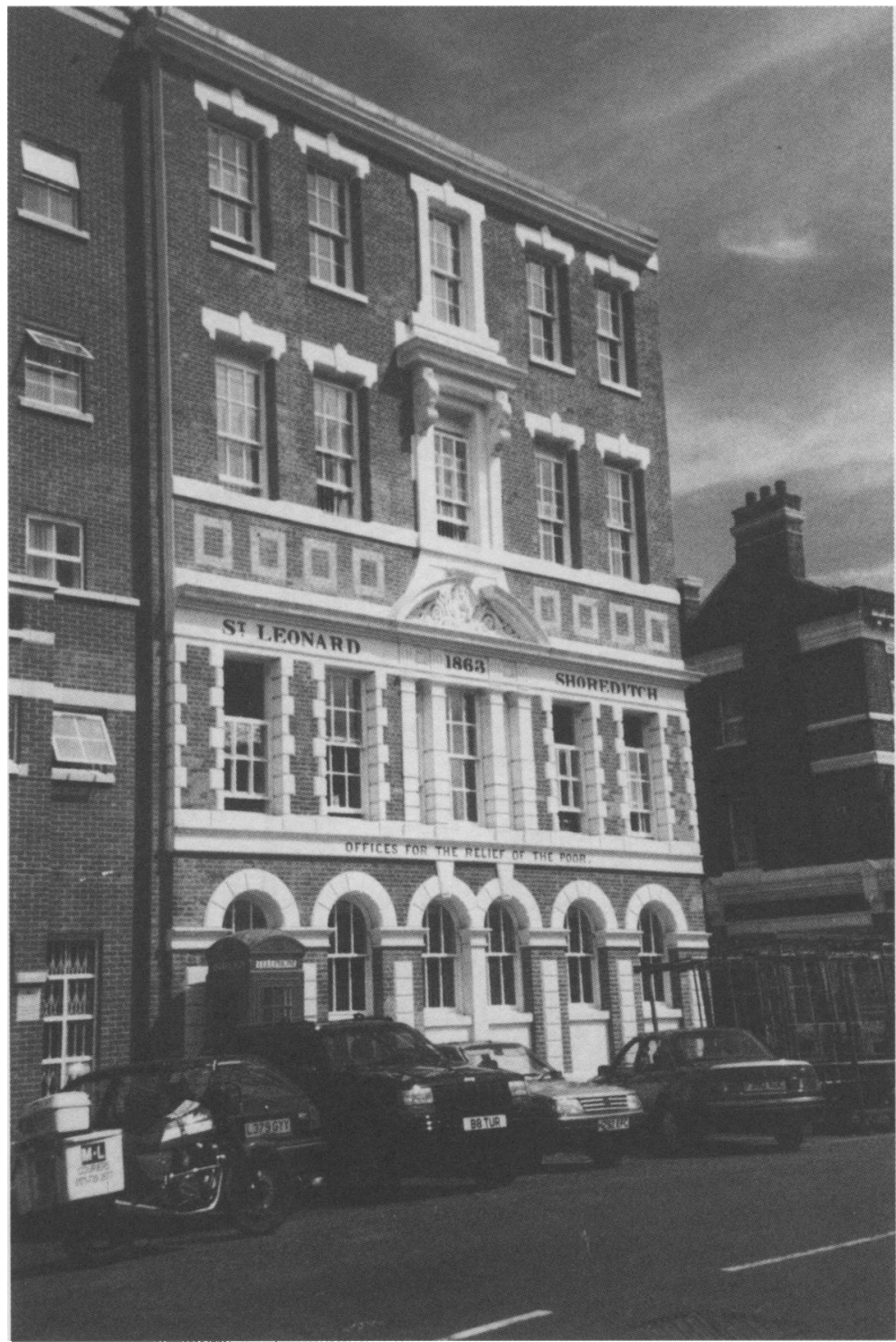

Figure 3: St Leonard's, Shoreditch, Offices for the Relief of the Poor, 1863. (Photograph by the author, 1998.)

The question of the condition of the insane in workhouses is one to which we have recently called earnest attention. Whether a few old and harmless imbecile patients may not properly be left in the workhouses is not a matter of very great moment; but that it is entirely unjustifiable to keep in the workhouse for one hour longer than is absolutely necessary an 


\section{Elaine Murphy}

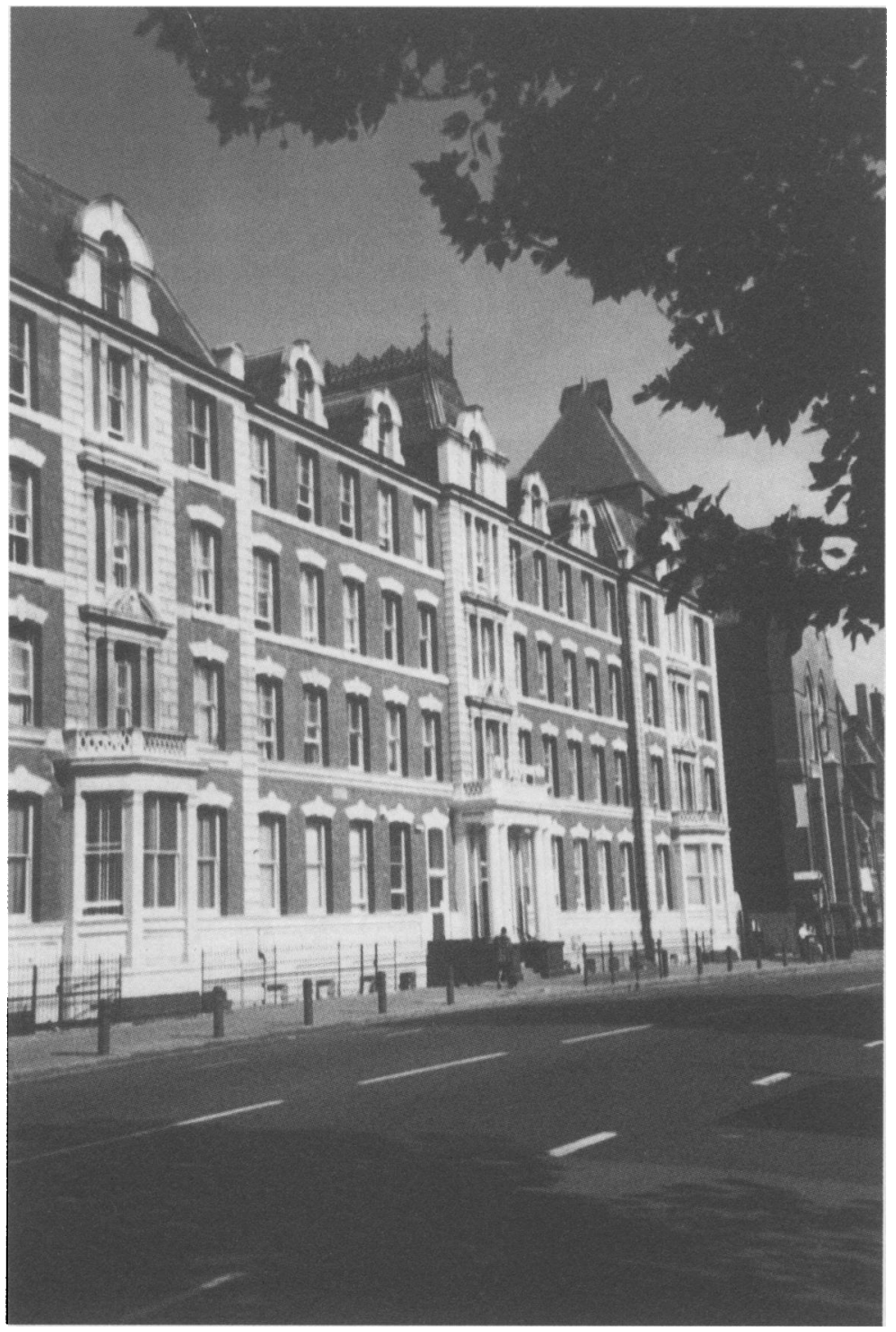

Figure 4: Shoreditch Workhouse Infirmary, 1865. (Photograph by the author, 1998.)

acute case of insanity, anyone who knows what are the requirements of treatment in such cases, and what workhouses at present are, must feel most strongly. ${ }^{88}$

${ }^{88}$ 'The Medico-Psychological Association', Lancet, 1865, ii: 97. 
Treatability was what excited the doctors. The acutely mad were welcome in the asylum; idiots and old dements languishing in disgraceful workhouses were not their concern.

\section{The Metropolitan Poor Act, the Defeat of the Guardians and the Lunacy Commissioners}

The minutes of the east London guardians' meetings in the 1860s are less varied in their characteristics than at their formation. The dull hand of central directive had curbed initiative and enthusiasm. Energetic men seeking influence and a challenge had been absorbed by the boards of works established in 1855 under the central direction of the Metropolitan Board of Works. "Public Health" had become a matter of sanitary engineering, clean water and fragrant air. ${ }^{89}$ Men interested in the relations between poverty, social justice and health care had been sidelined or converted to the religion of sewers and fine buildings, leaving the guardians to mop up the spillage of human frailty. The metropolitan guardians were left with the sick and the mad.

Hanwell was full; Colney Hatch was full; the lunatic merry-go-round was in constant danger of seizing up. "There is excessive pressure for accommodation at all Metropolitan licensed houses receiving paupers, which have been constantly filled to their utmost limits." 90 The old Lunacy Commissioners' cry for more, more, more lunatic places was never satisfied. ${ }^{91}$ East London guardians coped with the burgeoning numbers of mentally dependent paupers by expanding their own workhouses, building new separate workhouse infirmaries as decreed by the Poor Law Board in 1863 and by energetic tracking of "relieved" and "recovered" patients through the county asylums and licensed houses. This ensured no one occupied a place a week longer than was necessary. The Commissioners in Lunacy reluctantly agreed in 1868 to increase the licence numbers at Hoxton House and Camberwell Asylums to accommodate another forty-five paupers, but this barely touched the metropolitan "problem". 92

Gathorne-Hardy, the newly appointed President of the Poor Law Board, noted with some alarm in 1866 that the London workhouses contained among the 14,000 "old and infirm" 50 children and 2,000 adults classed as insane. ${ }^{93} \mathrm{He}$ regarded these highly dependent paupers with specialized needs as an unfortunate cause of the overcrowding which lay at the root of most workhouse evils. Gathorne-Hardy cleverly presented his plans for the creation of "auxiliary asylums" as an endorsement of the Lunacy Commission's recommendation. In effect, however, the new institutions were to be administered not by the Justices but by a new organization, a District Asylums Board, a hybrid creature ingeniously designed to incorporate local representation elected from the boards of guardians but with a healthy core of fifteen

\footnotetext{
${ }^{89}$ Christopher Hamlin, Public health and social justice in the age of Chadwick, London,

Cambridge University Press, 1998, pp. 335-41.

${ }^{90}$ Twentieth annual report of the Commissioners in Lunacy, PP 1866, XXXII, p. 7.

${ }^{91}$ Peter McCandless, 'Build! Build! The controversy over the care of the chronically
}

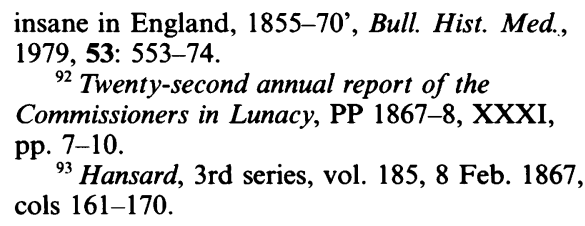
1979, 53: 553-74.

${ }_{92}$ Twenty-second annual report of the Commissioners in Lunacy, PP 1867-8, XXXI, pp. 7-10.

${ }^{93}$ Hansard, 3rd series, vol. 185, 8 Feb. 1867 , cols $161-170$. 


\section{Elaine Murphy}

central Poor Law Board nominees. Gathorne-Hardy's Metropolitan Poor Bill of 1867, which established the Metropolitan Asylums Board, marked the triumph of the Poor Law Board over the Lunacy Commissioners. The Poor Law Board inspectors had put obstacles in the way of the Lunacy Commissioners' discharge of their duties in workhouses for years; Gathorne-Hardy's bill ensured the Poor Law Authorities a final victory.

Gathorne-Hardy had served as a guardian in a Kent union and was sensitive to parochial autonomy. He admitted that "the role of guardian is one of great difficulty and delicacy". ${ }^{94}$ The Metropolitan Poor Bill was primarily designed to address the pressing political demands for decent infirmaries for the 21,000 sick paupers in metropolitan workhouses, and the recurrent outbreaks of smallpox, cholera and other fevers. The bill proposed an entirely new system of medical governance for London that effectively imposed central control over planning but appeared to provide safeguards for local government autonomy. Lunatics, children over two, fever and smallpox cases, were to be removed altogether to new institutions under the management of a central body. All other sick paupers would be provided for in separate workhouse infirmaries in the local district, which would be under the direction of asylum district committees accountable to the new central board.

The new Metropolitan Common Poor Fund was understandably popular in the East End, since the burden of poor relief was to be apportioned more evenly between parishes and unions on a proportional basis according to demand. While the cherished link between local rates and local relief was severed, this was highly advantageous to impoverished areas. Since the Common Poor Fund would bear centrally the costs of maintaining infectious and insane patients not only in the new asylums but also in county asylums and private licensed houses, significant potential was created for shifting the cost burden. No wonder the rate of "insanity" rose dramatically in London over the next few years. Many who would previously have been carted off to the workhouse "refractory" wards could be re-labelled, with the approval of the Lunacy Commissioners, and handed over to become a charge on the common budget. The Common Fund was available to all paupers with a medical certificate declaring that "the pauper is a chronic and harmless lunatic, idiot or imbecile". 95

The imbecile asylums did not fall within the jurisdiction of the Lunatics Acts for the purposes of certification of patients. The expense and inconvenience of hiring a doctor external to the workhouse to give an opinion and then petitioning a magistrate, the required procedure for a county lunatic asylum, was made simpler. In its place, certification for the imbecile asylums required a simple triple declaration by a relieving officer, the workhouse or district medical officer and a guardian, that the pauper fitted the criteria for admission. ${ }^{96}$ It was all too easy. At the same time, the Poor Law Board had acquired a mechanism for coercing the guardians into acceding

\footnotetext{
${ }^{94}$ Ayers, op. cit., note 73 above, p. 17.

${ }^{95}$ For a detailed description of the operation of MAB finances and the Common Fund, see Ayers, op. cit., note 73 above, Appendix IV, pp. 313-17.
} 
to other central demands through the operation of their powers to veto all capital expenditure.

Gathorne-Hardy's bill was ingenious and politically astute. In reality it chained the guardians to central imperatives but at the same time it created the impression of greater guardian participation in central decision making; a brilliant piece of administrative sleight-of-hand. The guardians did not want any further expansion of the county asylum system, which they thought expensive and beyond their influence. The one or two justices ex-officio on all the boards of guardians were not perceived to represent the ratepayers' interests in the meetings of the Middlesex Quarter Sessions. The proposed arrangements provided for the erection of new, cheaper institutions and gave the guardians the notion that they were retaining some control over policy and costs.

The Metropolitan Poor Act of 1867 was a serious blow to the Lunacy Commissioners. The bill was clearly designed to sidestep the Lunatics Acts and stop the justices widening their influence over lunacy matters. ${ }^{97}$ Shaftesbury protested to Gathorne-Hardy, pointing out that under the 1845 Act the two central inspectorates "shared the power of making regulations applicable to Lunatic Wards in workhouses. no arrangements can be made without the concurrent approval of both Boards." 98

Under the Metropolitan Poor Bill District Asylums are to be considered workhouses within the Lunacy Acts. Powers given to (Lunacy) Commissioners would practically cease to exist. District asylums will be filled with insane inmates over whom or for their proper accommodation and care the Lunacy Commissioners will have no authority whatever.

That of course was precisely what Gathorne-Hardy planned. Shaftesbury was a poor political negotiator, naively candid and trusting. He won arguments by sheer force of his assumed moral superiority. In an ambiguous moral situation such as this he floundered, lacking the intellect and capacity for deviousness to plot tactics. Shaftesbury walked round to Somerset House with his letter of protest to see Gathorne-Hardy in person. The formal response, a straight put-down, came from the Poor Law Board Secretary, Earle. The Board intended to have oversight of the new institutions and there would therefore be ample oversight, that the inmates would be "harmless" anyway and that the Lunacy Commissioners could visit and the Board "would be pleased to receive reports as now".99

Two huge cheap imbecile asylums were built by the Asylums Board, one south of the river at Caterham, Surrey and one in the north at Leavesden, Hertfordshire. Designed to take 1500 paupers each, they were of course rapidly expanded to absorb the free-for-all created by the Common Poor Fund. Within five years they jointly had nearly 4000 beds. The apotheosis of cheap human warehouses, the barn-like identical dormitories had 80 beds each. "Living rooms" were designed for 150 people. Architecturally featureless, barrack-like, these warehouses still stand as a testament to mean-spirited committee thrift.

\footnotetext{
${ }^{97}$ Twenty-second annual report of the Commissioners in Lunacy, PP 1867-8, XXXI, p. 47.

${ }^{98}$ Letter from Shaftesbury to Gathorne Hardy, 12 May 1867, PRO, MH19/170, letter 8905.
} 


\section{Elaine Murphy}

The metropolitan unions did not wait for the imbecile asylums to be built before taking advantage of the new financial inducements provided by the Common Poor Fund. The increase in inmates of unsound mind in workhouses, the Lunacy Commissioners noted, "has been entirely in the provincial workhouses and especially in Lancashire and Yorkshire. In the Metropolitan district there has been a decrease owing to the removal of large numbers to the provincial county asylums." 100 The pattern of care in the metropolis was beginning to diverge from the rest of England and Wales as a direct result of the financial inducement offered by the Common Poor Fund. ${ }^{101}$

The Lunacy Commissioners pressed on with their campaign for a third Middlesex county asylum. ${ }^{102}$ The impoverished East End contributed by far the largest number to those identified in Middlesex as still without the benefit of an asylum, either in a workhouse or at home. ${ }^{103}$ The majority of eastern unions retained their insane wards. In 1870 there were 500 or so insane in local workhouses and workhouse infirmaries, most destined for the imbecile asylums but some waiting for a vacancy in a local county asylum. The best way for the guardians to take full advantage of the Common Poor Fund was to give their fullest support to more asylums of every possible description.

\section{Concluding Remarks: \\ The Lunacy Commission's Impact on the Guardians}

Debates about whether the Lunacy Commissioners were effective or influential depend on whether the question pertains to their local visitorial inspectorate role or to their central policy achievements. Hervey judged the Commissioners to be effective locally in Kent in their early years, within the narrow confines of their remit. ${ }^{104}$ Mellett thought their remit so constrained it prevented them doing very much at all, and Bartlett found their role to be largely conciliatory and weak in the east Midlands. ${ }^{105}$ Forsythe, Melling and Adair in contrast found the Commission "authoritative and successful" in Devon. ${ }^{106}$

Local Commissioners had only as much influence as individual members could exert through force of personality, negotiating skill and tenacity. Commissioners were generally far more constrained in their relationships with Poor Law officials and guardians about conditions in workhouses than with public asylums and magistrates. Their incrementalist, conciliatory approach was unsuited to dealing with

\footnotetext{
${ }^{100}$ Ayers, op. cit., note 73 above, p. 49.

${ }^{101}$ Ibid., p. 47.

102 Ibid., p. 49.

${ }^{103}$ Twenty-third report of the Commissioners in Lunacy, PP 1869, XXVII, Appendix K, p. 258.

${ }^{104}$ Hervey, op. cit., note 8 above, pp. 455-64.

${ }^{105}$ Mellett, op. cit., note 8 above, p. 243; Peter Bartlett, 'The Poor Law of lunacy: the administration of pauper lunatics in mid-
}

\footnotetext{
nineteenth century England with special reference on Leicestershire and Rutland', PhD thesis, University of London, 1993, pp. 266-7, 294; Bartlett, op. cit., note 9 above, pp. 213-18. ${ }^{106}$ Bill Forsythe, Joseph Melling, Richard Adair, 'Politics of lunacy: central state regulation and the Devon Pauper Lunatic Asylum', in Melling and Forsythe (eds), op. cit., note 4 above, pp. 68-92,
} 
uncooperative local guardians and officials. The Commission failed miserably to get major improvements in insane wards of the eastern metropolitan workhouses compared with the "Lancet Commission". Shaftesbury, however, had sufficient standing and parliamentary clout to ensure that for twenty-five years the corporate Commission influenced central government's ideology of care in asylums and licensed houses, even if practice fell short of the ideal. Ultimately though, the Commission's aspirations to annexe the universe of imbeciles to their lunatic empire ran aground, although their annual reports set the moral tone and care standards for a generation of asylums.

It has long been accepted that the rise in numbers of detained lunatics outstripped the growth of poor relief recipients and increased at a rate beyond that expected from population growth between 1840 and $1900 .{ }^{107}$ The main increase in institutionalization rates for insanity in Middlesex beyond that predicted by population growth occurred after the Union Chargeability Act and the Metropolitan Common Poor Fund in the late 1860 s produced an irresistible financial incentive. By 1871 , all but 4.6 per cent of chargeable lunatics in Middlesex were either in asylums or workhouses. ${ }^{108}$ The tight reciprocal bond between the parish ratepayers' contribution and union expenditure was weakened for lunatics before any other group of paupers by a clause in the 1853 Lunatics Amendment Act which made unions rather than parishes the accountable units of administration responsible for paying asylum fees. ${ }^{109}$ It was another twelve years before the Union Chargeability Act of 1865 applied the same ruling to costs of relief for all other classes of pauper and provided an even greater advantage, from the point of view of the poorer parishes, of a more equitable rating system across rich and poor unions. This enhanced the spending power of the east London unions without drawing further on their beleaguered ratepayers. Since these were the poorer parishes with the greatest burden of paupers of all kinds, including the insane, it is not surprising that unions increased their use of all institutional options. In addition to the financial advantages, the removal of dependent and difficult paupers made life easier for local workhouse staff.

Two years later, the 1867 Metropolitan Poor Act severed the link between asylum funding and ratepayers' pockets by the creation of the Common Poor Fund, a central pot on which unions could draw to place any number of designated cases. As Cochrane remarked in his paper describing the London County Council's later unwise incentive system, the 1867 Act produced "immense and disproportionate growth in Poor Law lunatic asylums and other forms of poor relief". ${ }^{110}$ It is not surprising to find that almost any pauper with a hint, a suspicion, of eccentricity, indecorous habits or behavioural inconvenience, was a candidate for the asylum. Gathorne-Hardy's objective was to provide sufficient financial incentives for the

${ }^{107}$ Scull, op. cit., note 1 above, pp. $335-44$, $36-70$, see Table 10, p. 362 , and fig. 23 , p. 369.

${ }^{108}$ Mellett, op. cit., note 8 above, Table 9 ,

'Relative distribution of pauper lunatics and idiots 1871 and $1889^{\prime}$, p. 58.

${ }^{109}$ Lunatics Amendment Act 1853, 16 \& 17 Vic. c. $96 \& 97$.

\footnotetext{
${ }^{110}$ David Cochrane, 'Humane, economical and medically wise: the LCC as administrators of Victorian lunacy policy', in W F Bynum, $\mathbf{R}$ Porter, M Shepherd (eds), The anatomy of madness, vol. 3, Asylum and its psychiatry, London, Routledge, 1988, p. 251.
} 


\section{Elaine Murphy}

guardians to cede power to the central Poor Law bureacracy. The Common Poor Fund was the wooden horse that drew the guardians into Troy. Lunatics became proxy parcels of cash, who, as they moved from local care to a remote asylum, provided the vehicle through which government centralist control of the dependent unpopular poor was achieved. 